\section{Bedre og billigere med tilpasset ryggbehandling}

\author{
Gradering av korsryggssmerter og \\ tilpasset behandling gir bedre effekt \\ og bedre utnyttelse av ressurser.
}

I en engelsk studie ble 851 pasienter med smerteutstråling fordelt $i$ tre grupper etter antatt prognose (god, middels, dårlig) basert på et validert prognostisk screeninginstrument (1). Av disse fikk 586 individuelt tilpasset behandling - enten kun rådgivning om tilstanden eller rådgivning pluss vanlig fysioterapi eller psykomotorisk fysioterapi. Resten av pasientene fikk den behandlingen som allmennlege og fysioterapeut anså som best.

Etter fire og 12 måneder hadde pasientene i intervensjonsgruppen signifikant mindre helseplager enn pasientene i kontrollgruppen. Kostnad-effekt-analyser viste at optimalisert behandling ga bedre utnyttelse av behandlingsressursene. ryggsmerter er veldig forskjellige og trenger ulik behandling, sier Peer H. Staff, tidligere akutte korsryggssmerter med eller uten

- Denne studien viser at pasienter med

overlege i fysikalsk medisin og rehabilitering ved Oslo universitetssykehus, Ullevål. - Særlig har de med sammensatte plager, problemer og årsaksforklaringer høyere risiko for langvarig sykefravær og varig uførhet. Tilstanden er da underordnet situasjonen og krever kognitiv behandling og atferdstrening. Samtidig er det svært mange pasienter som bare i beskjeden grad trenger hjelp av helsevesenet.

Det skjemaet som ble brukt, STarT Back, er enkelt, med bare ni spørsmål, men det har vist seg egnet for prognostisk screening i allmennpraksis. Det kan tenkes at gruppering av ryggpasienter tidlig i sykdomsforløpet og individualisert behandling kan redusere de store utgiftene som ryggsmerter påfører samfunnet, sier Staff.

Johan Edvard Tellum
biridoc@gmail.com
Oslo
Litteratur
1. Hill JC, Whitehurst DG, Lewis M et al. Comparison
of stratified primary care management for low
back pain with current best practice (StarT Back):
a randomised controlled trial. Lancet 2011; 378:
$\quad 1560-71$.

\section{Malariamygg resistent mot insektmiddel}

\author{
To år etter distribusjon av pesticidbehandlede myggnett så man økt resis- \\ tens mot insektmidlet hos malariamygg, og hyppigheten av malariaanfall \\ i befolkningen var nesten tilbake til det den var i utgangspunktet.
}

I fireårsperioden januar 2007-desember 2010 ble innbyggerne i en landsby i Senegal fulgt opp ved feberanfall, og bekreftede tilfeller av malaria ble behandlet med artesunat og amodiaquin i kombinasjon (1). Halvannet år etter studiestart ble det utdelt myggnett behandlet med det insektdrepende midlet deltamethrin til alle landsbybeboerne. Hver studiemåned ble det gjort nattlig innsamling av Anopheles gambiae-mygg.

Hyppigheten av malariaanfall var 5,45 (95\% KI 4,90-6,05) per 100 personmåneder før distribusjonen av myggnett, 0,41 10,29$0,55)$ de to første årene etter distribusjonen og 4,57 (3,54-5,82) i siste halvår av studien. I 2010 var $37 \%$ av A gambiae-myggene resistente mot deltamethrin. Forskerne fant en økende forekomst av en bestemt resistensmutasjon hos myggen - fra $8 \%$ i 2007 til $48 \%$ i 2010. Økt resistens hos A gambiae

\section{Øyunn Holen}

Infeksjonsmedisinsk avdeling

Oslo universitetssykehus, Ullevål

\section{Litteratur}

1. Trape J, Tall A, Diagne N et al. Malaria morbidity and pyrethroid resistance after the introduction of insecticide-treated bednets and artemisinin-based combination therapies: a longitudinal study.

Lancet Infect Dis 2011; 12: 925-32.

\section{Kortvarig ryggbehand- ling kan være best}

\author{
For sykmeldte med ryggsmerter \\ og et positivt forhold til arbeids- \\ plassen er kortvarig behandling \\ like bra som mer omfattende, \\ tverrfaglig tilnærming.
}

En tidligere studie viste at kortvarig behandling fikk like mange av dem som var sykmeldt for ryggsmerter tilbake i arbeid som dem som fikk et multidisiplinært behandlingsopplegg. I en subgruppeanalyse ble 351 pasienter gruppert etter trivselsmessige faktorer knyttet til arbeidsplassen (1). Gruppene ble sammenliknet med henblikk på hvordan de nyttiggjorde seg en kortvarig intervensjon versus tverrfaglig behandling. Utfallsmålene var symptomlindring og friskmelding.

Kortvarig intervensjon og mer langvarig tverrfaglig behandling var likeverdige når det gjaldt å få folk tilbake i arbeid. Sykmeldte med et positivt forhold til arbeidsplassen nyttiggjorde seg i større grad den kortvarige intervensjonen. Sykmeldte med lav tilfredshet i jobbsituasjonen og liten grad av kontroll hadde best effekt av tverrfaglig tilnærming.

- Dette er en viktig studie av stor relevans for rehabilitering og behandling av pasienter med langvarige ryggsmerter, sier professor Aage Indahl ved Universitetet i Bergen og Sykehuset i Vestfold. - Studien, som bygger på det som er gjort i Norge på dette området, er den første der man har sammenliknet kortvarig intervensjon og et tyngre tverrfaglig tiltak med tanke på det å komme tilbake i arbeid.

Resultatene må beskrives som oppsiktsvekkende, sier Indahl. - Korte, enkle intervensjoner ser ut til å være effektive sammenliknet med mer omfattende tiltak. Mange institusjoner lever av å tilby tverrfaglige intervensjoner over flere uker. Forskning må i større grad rette oppmerksomheten mot at lite behandling kan være det beste for pasientene, sier Indahl.

\section{Marit A. Kamøy \\ marit@kamoey.no Oslo}

oeyhole@online.no
Litteratur

1. Stapelfeldt CM, Christiansen DH, Jensen OK et al. Subgroup analyses on return to work in sick-listed employees with low back pain in a randomized trial comparing brief and multidisciplinary intervention. BMC Musculoskelet Disord 2011; 12: 112 